University of Nebraska - Lincoln

DigitalCommons@University of Nebraska - Lincoln

Educational Psychology Papers and

Publications

Educational Psychology, Department of

2011

\title{
Social Meaning of Alcohol-Related Flushing Among University Students in China
}

Ian M. Newman

University of Nebraska-Lincoln, inewman1@unl.edu

Izumi Jinnai

Tama City International Center and Tokyo English Life Line, Tokyo, Japan

Jie Zhao

National Opinion Research Center, Chicago, IL, USA

Zhaoqing Huang

University of Southern California, Alhambra, CA, USA

Jia Pu

University of Wisconsin-Madison, Madison, WI, USA

See next page for additional authors

Follow this and additional works at: https://digitalcommons.unl.edu/edpsychpapers

Part of the Educational Psychology Commons, and the Public Health Commons

Newman, Ian M.; Jinnai, Izumi; Zhao, Jie; Huang, Zhaoqing; Pu, Jia; and Qian, Ling, "Social Meaning of Alcohol-Related Flushing Among University Students in China" (2011). Educational Psychology Papers and Publications. 172.

https://digitalcommons.unl.edu/edpsychpapers/172

This Article is brought to you for free and open access by the Educational Psychology, Department of at DigitalCommons@University of Nebraska - Lincoln. It has been accepted for inclusion in Educational Psychology Papers and Publications by an authorized administrator of DigitalCommons@University of Nebraska - Lincoln. 


\section{Authors}

Ian M. Newman, Izumi Jinnai, Jie Zhao, Zhaoqing Huang, Jia Pu, and Ling Qian 


\section{Social Meaning of Alcohol-Related Flushing Among University Students in China}

Ian M. Newman, PhD, Izumi Jinnai, MA, Jie Zhao, MS, Zhaoqing Huang, MA, Jia Pu, MA, and Ling Quan, MD, PhD

\section{Abstract}

This study explored drinking patterns, alcohol-related flushing, and ways students themselves and other people respond to flushing in drinking situations. Of 1080 Chinese undergraduate university students, $725(67.1 \%)$ returned the completed surveys. $80 \%$ of the students were drinkers (93\% of males and $69 \%$ of females); $68 \%$ of the drinkers were flushers. Most of the students (59.3\%) said flushing had no special meaning, i.e. would ignore flushing; $54 \%$ of flushers said they could keep drinking "but less" when they flush; $27 \%$ of students said that a flushing person should stop drinking; however, if the flushing person is a girl, $89 \%$ of the students said the girl should drink less or stop. If the flushing person was a boy, $61 \%$ of students said he should drink less or stop. The data do suggest gender differences in the understanding of and social reaction to alcohol-related flushing, and these differences raise interesting questions as to how flushing acts as a potential protective factor against alcohol misuse.

Keywords: alcohol flushing, acetaldehyde, ALDH, China, university students, alcohol beliefs 


\section{INTRODUCTION}

\section{Background}

Alcohol is recognized as contributing to global health problems. ${ }^{1}$ It is also recognized as playing an important role in the life of most societies. Alcohol is an important ingredient in food and medicine, and it is often used in ritual ceremonies. Alcohol beverages are used to express hospitality and friendship, facilitate communication, and modify mood. They are used in practically all societies and have accumulated reputations ranging from ecstasy to evil.

Alcohol affects physiology in a predicable manner, but how these inward physiological changes are expressed in outward behavior is, in large part, learned from one's culture. ${ }^{2}$ In some societies, people under the influence of alcohol become violent, while in other societies people become contemplative. In some societies it is acceptable to become loud and active under the influence of alcohol, while in other cultures such behavior is rare.

Generally, alcohol's most visible effects are in behavior, but there is one exception: alcohol-related flushing, which is common among Asian populations. Flushing is typically characterized by reddening of the face, upper body, or a combination of both, and in some cases other adverse effects like skin rashes, headaches, hot flashes, increased heart rate, nausea, and dizziness. ${ }^{3-5}$ Wall \& Ehlers ${ }^{6}$ and Luo et al. ${ }^{7}$ estimate that half of Chinese, Japanese, Koreans and other Asian people possess a genetic predisposition to flush, compared to 3-12\% of Caucasians. 


\section{Alcohol and the Flushing Reaction}

Flushing appears to be genetically controlled. When consumed, alcohol is absorbed throughout the digestive tract beginning in the mouth. Most absorption takes place in the stomach (20\%) and in the small intestine (80\%). The absorbed alcohol is metabolized by the liver in a two-stage process. In the first stage the enzyme alcohol dehydrogenase (ADH) converts alcohol to acetaldehyde, which is toxic to the body. In the second stage the enzyme aldehyde dehydrogenase (ALDH) converts the acetaldehyde to acetate (acetic acid), which is not toxic. The acetate is further broken down into water and carbon dioxide and excreted by the body in urine and exhaled air. ${ }^{7}$ Alcohol-related flushing occurs in some drinkers when acetaldehyde in the blood increases, usually as a result of slow conversion of acetaldehyde to acetate.

ALDH consists of four groups of enzymes. One of the groups, called ALDH2, is primarily responsible for the conversion of acetaldehyde to acetate. The ALDH2 group has two variants: $\mathrm{ALDH} 2^{1}$ and $\mathrm{ALDH} 2^{2}$. The $\mathrm{ALDH} 2^{2}$ variant is associated with the slow conversion of acetaldehyde. ${ }^{7-9}$ Each person inherits one gene from each parent. ALDH2 ${ }^{2}$ homozygous individuals (people who inherit two $\mathrm{ALDH} 2^{2}$ genes) have more severe reactions to alcohol, including flushing, than people who are heterozygous (people who inherit one of each ALDH2 ${ }^{1}$ and $\mathrm{ALDH} 22^{2}$ ) and people who are "typical" homozygous (inherited two copies of ALDH2 ${ }^{1}$ ). ${ }^{7,8}$

In addition to flushing, the $\mathrm{ALDH} 2^{2}$ genotype yields other physiological consequences. For example, Wall et al. ${ }^{10}$ found that people who inherited the ALDH2 2 genotype experienced more severe hangovers than those who did not. Luczak et $\mathrm{al}^{9}$ reported that, regardless of gender, heterozygous individuals who drank alcohol were more likely to report subjective physical reactions such as dizziness and drunkenness. Luczak, Shea, et $\mathrm{al}^{111}$ found that college students having the $\mathrm{ALDH} 2^{2}$ allele reported far fewer alcohol-induced blackouts. Wall, Thomasson, et 
al ${ }^{12}$ reported that those who were heterozygous for ALDH2 tended to have more positive responses to alcohol consumption and were less likely to experience severe aversive reactions than those who were $\mathrm{ALDH} 2^{2}$ homozygous. These possible genetic influences were noted by Unger whose study of twins reported that in a Chinese sample experimentation with alcohol was more likely to be heritable compared to experimenting with tobacco, which was more likely to be familial. ${ }^{13}$

\section{Flushing Reaction and Drinking Patterns}

Studies looking for an association between drinking and flushing reaction have not been done with Chinese university students. On the general question of associations between flushing reaction and drinking, we review here some studies with Asian populations, with the caveat that these studies among, for example Asian-Americans or Japanese, may not be culturally or contextually specific enough to apply to this research.

A few studies suggest that those who flush and those who possess the ALDH2 ${ }^{2}$ genotype drank less than those who did not. ${ }^{14-17}$ This same pattern has been observed among Asian Americans and Native American Indians. ${ }^{5}$ Asians have lower rates of alcohol dependence and lower risk of alcoholism and related problems than non-Asians ${ }^{8,9}$ These findings suggest that this physiological sensitivity to alcohol, exhibited as flushing, serves as a protective factor against excessive drinking. ${ }^{6,14,15,17}$

However, any observer of drinking behavior in Asia recognizes that many who flush continue to drink. Conversations about flushing with Asian drinkers and nondrinkers do not suggest a consensus about the meaning of flushing. And, some researchers note that the association between drinking patterns and ALDH2 is not always consistent. Nakawatase et al ${ }^{18}$ 
found that those who drank less were only the fast flushers - those who flushed after one cup of alcohol or less. They noted that fast flushers, in a Japanese-American sample, drank less than nonflushers, but they were unable to establish any relationship between alcohol use and ALDH genotype. Hendershot et $\mathrm{al}^{19}$ found no relationship between ALDH2 gene status and alcohol use among Chinese-American and Korean-American college students.

Johnson ${ }^{17}$ and Fromme et $\mathrm{al}^{3}$ found that individual differences in reaction to alcohol may impact drinking patterns but suggested that the genetic variation was only one of many determinants. Suzuki et $\mathrm{al}^{20}$ suggested that many people have positive perceptions of the role of alcohol in socializing and providing pleasure and therefore are more likely to drink regardless of any negative consequence, thus minimizing differences between flushers and nonflushers. Nakawatase et $\mathrm{al}^{18}$ found that social and environmental factors such as peer pressure, availability of alcohol, and group memberships were stronger predictors of alcohol use among college students than physiological factors. Stacy et al $^{21}$ reported that positive expectancies about drinking alcohol were the most salient determinant in decisions to drink or not drink alcohol. Parrish et $\mathrm{al}^{22}$ examined how flushing was interpreted and what role embarrassment had on drinking patterns. Among Japanese and Japanese-Americans, regardless of location (Japan or United States), individuals who felt more embarrassment about their flushing tended to drink less. In addition, women who flushed felt more embarrassment and drank less than men who flushed. Johnson \& Nagoshi ${ }^{5}$ suggest Chinese, Koreans, and Japanese have a predisposition to feel shame and guilt, and avoid drinking if they flush. Newlin ${ }^{23}$ concluded that the aversive experiences following alcohol consumption may not only be for physiological reasons but also for social reasons. 


\section{The Objective of This Study}

This study explored the following questions:

What is the social meaning of alcohol-related flushing and does the meaning differ by gender, between flushers and non-flushers, and between drinkers and nondrinkers?

What do students who flush feel about their own flushing and are there gender differences?

How do students respond to other students who flush and are there gender differences?

What do students believe will be the reaction to flushers by other students and are there gender differences?

\section{METHOD}

Participants

One thousand and eighty undergraduate students completed the 53-item Chineselanguage questionnaire. Data were gathered from intact classes in universities in Beijing (32.4\%), Jinan (23.7\%), Wuhan (20.0\%) and Xianning (23.9\%). Beijing and Jinan are in northeastern China, Wuhan and Xianning are in central China.

\section{Measures}

The questionnaire was a modified version of one used by Zhang et al ${ }^{24}$ among young people in central China. This modified questionnaire was pilot tested and revised.

\section{Procedures}

The sampled classrooms were not selected randomly but were selected purposely to represent a wide cross-section of undergraduate students. All students in the sampled classes at 
the time of data collection completed the questionnaire. A statement on the front page of the questionnaire described the purpose of the study, defined alcohol in specific terms, and assured both anonymity and confidentiality. The statement was read aloud to the students. Students sat in rows apart from other students when completing the questionnaire and were not permitted to talk during data collection. Classroom teachers were not present; the survey was overseen by trained data collectors from the respective provincial health education institute.. Authorities at the cooperating universities gave permission for the survey and approved survey procedures. Data were analyzed at the University of Nebraska-Lincoln with the permission of China's National Health Education Institute. The UNL institutional review board approved the project. The records contained no individual identifying information.

\section{Analysis}

Questionnaires from 221 students who answered questions inconsistently and 134 who returned questionnaires with missing data were eliminated from the sample. Thus 725 students (67.1\%) of the sample provided complete surveys.

\section{RESULTS}

Table 1 shows the demographic characteristics of the students in the sample: 339 males $(46.8 \%)$ and 386 females $(53.2 \%) ; 77 \%$ of the students were 20 to 22 years of age. $48.4 \%$ were first- or second- year students, $45 \%$ were third- year students, $6.6 \%$ fourth- year students. 
Table 1. Demographic Characteristics of the Students in the Sample

\begin{tabular}{ccccrcr}
\hline & \multicolumn{2}{c}{$\underline{\text { Male }}$} & \multicolumn{2}{c}{ Female } & \multicolumn{2}{c}{ Total } \\
& $\mathrm{N}$ & $\%$ & $\mathrm{~N}$ & $\%$ & $\mathrm{~N}$ & $\%$ \\
\cline { 2 - 6 }$\leq 19$ & 34 & 10.0 & 58 & 15.0 & 92 & 12.7 \\
20 & 92 & 27.1 & 85 & 22.0 & 177 & 24.4 \\
21 & 100 & 29.5 & 114 & 29.5 & 214 & 29.5 \\
22 & 69 & 20.4 & 103 & 26.7 & 172 & 23.7 \\
$\geq 23$ & 44 & 13.0 & 26 & 6.8 & 70 & 9.7 \\
total & 339 & 100.0 & 386 & 100.0 & 725 & 100.0 \\
& & & & & & \\
& & & YEAR IN SCHOOL & & \\
Freshman & 99 & 29.2 & 69 & 17.9 & 168 & 23.2 \\
Sophomore & 97 & 28.6 & 86 & 22.3 & 183 & 25.2 \\
Junior & 112 & 33.0 & 214 & 55.4 & 326 & 45.0 \\
Senior & 31 & 9.1 & 17 & 4.4 & 48 & 6.6 \\
total & 339 & 100.0 & 386 & 100.0 & 725 & 100.0 \\
\hline
\end{tabular}

\section{Drinking Behaviors}

Self-reported drinking behavior was used to divide students into three groups. Students who had not drunk alcohol in the last 12 months were classified as nondrinkers, students who had drunk at least once in the last 12 months but not in the last 30 days were classified as occasional drinkers, and students who had drunk alcohol in the past 30 days were classified as current drinkers. Admittedly this is a rather gross classification, but it has proven useful in alcohol research with adolescents and young adults. Table 2 shows the distribution of drinking behavior by gender and age and year in school. The majority of current drinkers (64.8\%) were males, while the majority of occasional drinkers and non-drinkers were females $(58.4 \%$ and $83.4 \%$ 
respectively $(\chi 2(2, \mathrm{~N}=725)=97.428, p=.000)$. Drinking patterns did not appear to be related to age, but they were related to the number of years in school.

Table 2. Characteristics of the Drinkers and Nondrinkers

\begin{tabular}{|c|c|c|c|c|c|c|c|c|}
\hline \multirow{3}{*}{ GENDER } & \multicolumn{2}{|c|}{$\underline{\text { Non drinkers }}$} & \multicolumn{2}{|c|}{$\frac{\text { Occasional }}{\underline{\text { Drinkers }}}$} & \multicolumn{2}{|c|}{ Current Drinkers } & \multicolumn{2}{|c|}{ Total } \\
\hline & $\mathrm{N}$ & $\%$ & $\mathrm{~N}$ & $\%$ & $\mathrm{~N}$ & $\%$ & $\mathrm{~N}$ & $\%$ \\
\hline & & & & & & & & \\
\hline Male & 24 & 16.6 & 109 & 41.6 & 206 & 64.8 & 339 & 46.8 \\
\hline Female & 121 & 83.4 & 153 & 58.4 & 112 & 35.2 & 386 & 53.2 \\
\hline total & 145 & 100.0 & 262 & 100.0 & 318 & 100.0 & 725 & 100.0 \\
\hline \multicolumn{9}{|c|}{$\chi^{2}=97.428, p=.000$} \\
\hline \multicolumn{9}{|l|}{ AGE } \\
\hline$\leq 19$ & 20 & 13.8 & 37 & 14.2 & 34 & 11.0 & 92 & 12.7 \\
\hline 20 & 36 & 24.8 & 61 & 23.3 & 80 & 25.2 & 177 & 24.4 \\
\hline 21 & 47 & 32.4 & 84 & 32.1 & 83 & 26.1 & 214 & 29.5 \\
\hline 22 & 34 & 23.4 & 61 & 23.3 & 77 & 24.2 & 172 & 23.7 \\
\hline$\geq 23$ & 8 & 5.5 & 19 & 7.3 & 43 & 13.5 & 70 & 9.7 \\
\hline total & 145 & 100.0 & 262 & 100.0 & 318 & 100.0 & 725 & 100.0 \\
\hline \multicolumn{9}{|c|}{$\chi^{2}=12.858, p=.117$} \\
\hline \multicolumn{9}{|c|}{ YEAR IN SCHOOL } \\
\hline Freshman & 24 & 16.6 & 70 & 26.7 & 74 & 23.3 & 168 & 23.2 \\
\hline Sophomore & 38 & 26.2 & 67 & 25.6 & 78 & 24.5 & 183 & 25.2 \\
\hline Junior & 80 & 55.2 & 121 & 46.2 & 125 & 39.3 & 326 & 45.0 \\
\hline Senior & 3 & 2.1 & 4 & 1.5 & 41 & 12.9 & 48 & 6.6 \\
\hline Total & 145 & 100.0 & 262 & 100.0 & 318 & 100.0 & 725 & 100.0 \\
\hline$\chi^{2}=43.707$ & $=.000$ & & & & & & & \\
\hline
\end{tabular}

Flushing Type and Drinking Behavior

The drinkers $(n=580)$ were classified by whether or not they flushed and how much alcohol they consumed before they flushed. Drinkers who did not flush at all were classified as 
nonflushers (32.4\%). Drinkers who turned red in the face or neck or other body parts while drinking the first glass of alcohol or right after drinking the first glass and before the second glass were classified as fast flushers (26.6\%). Drinkers who turned red in the face and neck or other parts of the body while drinking the second glass of alcohol or afterwards were classified as slow flushers $(41.0 \%)$. No difference in flushing was noted by gender $(\chi 2=8.029, p=.018)$, age $(\chi 2=7.210, p=.514)$ or year in school $(\chi 2=9.233, p=.161)$

Table 3 shows drinking behavior by flushing type among drinkers. A larger proportion of both slow flushers and nonflushers were current drinkers $(\chi 2(2, \mathrm{~N}=580)=1.842, p=.398)$.

Table 3. Drinking Behavior and Flushing Among Drinkers

\begin{tabular}{|c|c|c|c|c|c|c|c|c|}
\hline & \multicolumn{2}{|c|}{$\underline{\text { Non flusher }}$} & \multicolumn{2}{|c|}{$\underline{\text { Fast flusher }}$} & \multicolumn{2}{|c|}{$\underline{\text { Slow flusher }}$} & \multicolumn{2}{|c|}{$\underline{\text { Total }}$} \\
\hline & $\mathrm{N}$ & $\%$ & $\mathrm{~N}$ & $\%$ & $\mathrm{~N}$ & $\%$ & $\mathrm{~N}$ & $\%$ \\
\hline $\begin{array}{l}\text { Occasional } \\
\text { Drinker }\end{array}$ & 78 & 41.5 & 75 & 48.7 & 109 & 45.8 & 262 & 45.2 \\
\hline $\begin{array}{l}\text { Current } \\
\text { Drinker }\end{array}$ & 110 & 58.5 & 79 & 51.3 & 129 & 54.2 & 318 & 54.8 \\
\hline total & 188 & 100.0 & 154 & 100.0 & 238 & 100.0 & 580 & 100.0 \\
\hline
\end{tabular}

\section{The Meaning of Alcohol-Related Flushing}

Students were asked if flushing meant a person should stop drinking, should drink more, or if flushing had no special meaning related to alcohol use. In this sample $26.8 \%$ said flushing while drinking alcohol meant a person should stop drinking, 13.9\% said a person flushing should drink more alcohol, and 59.3\% said flushing had no special meaning.

Males and females interpreted the meaning of flushing differently $(\chi 2=8.179, p=.017)$. Females were more likely $(31.1 \%)$ to think the flusher should stop drinking than males $(21.8 \%)$. 
Males were more likely to think flushing had no special meaning or that it meant that a person could drink more (Table 4). The meaning of flushing did not differ significantly by age or year in school. Beliefs about the meaning of flushing were unrelated to the individual student's likelihood to flush $(\chi 2=5.428, p=.246)$.

Table 4 The Meaning of Flushing by Gender

\begin{tabular}{lrrrrrr}
\hline & \multicolumn{2}{c}{ Male } & \multicolumn{2}{c}{ Female } & \multicolumn{2}{c}{ Total } \\
Flushing means... & $\mathrm{N}$ & $\%$ & $\mathrm{~N}$ & $\%$ & $\mathrm{~N}$ & $\%$ \\
\cline { 2 - 6 } Stop drinking & 74 & 21.8 & 120 & 31.1 & 194 & 26.8 \\
Drink more & 48 & 14.2 & 53 & 13.7 & 101 & 13.9 \\
No meaning & 217 & 64.0 & 213 & 55.2 & 430 & 59.3 \\
Total & 339 & 100.0 & 386 & 100.0 & 725 & 100.0 \\
\hline$\chi 2=8.179, p=.017$ & & & & & &
\end{tabular}

Nondrinkers were more likely (35.2\%) to believe flushing meant the person should stop drinking, compared to occasional drinkers (29.4\%) and current drinkers (20.8\%). More current drinkers (17.9\%) thought flushing meant a drinker should drink more, compared to nondrinkers $(11.7 \%)$ and occasional drinkers $(10.3 \%),(\chi 2(4, \mathrm{~N}=725)=16.619, p=.002)$.

\section{Students' Reactions to Their Own Flushing}

Table 5 shows the results of a question that asked the flushers about their reactions to their own flushing. This question focused on the flushers' own reaction to their flushing, as opposed to the earlier questions that asked about the general meaning of flushing. Only $26 \%$ of drinkers who flush answered they would stop drinking if they felt themselves flush. Gender differences were significant. Females $(33.7 \%)$ were more likely than males $(19.4 \%)$ to report that 
they would stop drinking. Males were more likely to report that they would keep drinking either a lesser amount $(55.9 \%)$ or the same amount $(23.2 \%) \cdot(\chi 2(3, \mathrm{~N}=392)=12.285, p=.006)$

Table 5. Flushers' Reaction to Their Own Flushing by Gender

\begin{tabular}{lrrrrrr}
\hline & \multicolumn{2}{c}{$\underline{\text { Male }}$} & \multicolumn{2}{c}{ Female } & \multicolumn{2}{c}{ Total* } \\
& $\mathrm{N}$ & $\%$ & $\mathrm{~N}$ & $\%$ & $\mathrm{~N}$ & $\%$ \\
\cline { 2 - 6 } Stop drinking & 41 & 19.4 & 61 & 33.7 & 102 & 26.0 \\
Keep drinking but less & 118 & 55.9 & 92 & 50.8 & 210 & 53.6 \\
Keep drinking same amount & 49 & 23.2 & 27 & 14.9 & 76 & 19.4 \\
Drink more & 3 & 1.4 & 1 & .6 & 4 & 1.0 \\
Total & 211 & 100.0 & 181 & 100.0 & 392 & 100.0 \\
\hline
\end{tabular}

$* 24$ students did not answer this question. $(\chi 2(3, \mathrm{~N}=392)=12.285, p=.006)$

Students' Reactions to Another Student's Flushing

The survey questionnaire asked the students what they would do in a drinking situation when they observed another person flushing.

When a man flushed more females (72\%) than males (49\%) would encourage a man who flushed to drink less or to stop drinking (Table 6). In the same situation more males (36.3\%) than females $(24.6 \%)$ would do nothing $(\chi 2(2, \mathrm{~N}=725)=50.745, p<=.0001)$.

Table 6. Personal Reaction to Man's Flushing

\begin{tabular}{lrrrrrr}
\hline What would you do if a man & $\mathrm{N}$ & \multicolumn{2}{c}{ Male } & \multicolumn{2}{c}{ Female } & \multicolumn{2}{c}{ Total } \\
flushed? & & & $\mathrm{N}$ & & $\mathrm{N}$ & \\
\cline { 2 - 6 } Encourage him to drink more & 50 & 14.7 & 13 & 3.4 & 63 & 8.7 \\
Encourage him to drink less or & 166 & 49.0 & 278 & 72.0 & 444 & 61.2 \\
stop & & & & & & \\
Do nothing & 123 & 36.3 & 95 & 24.6 & 218 & 30.1 \\
Total & 339 & 100.0 & 386 & 100.0 & 725 & 100.0 \\
\hline
\end{tabular}

$\chi 2=50.745, p<.0001$ 
When a woman flushed both males (84.7\%) and females (92.7\%) would encourage the woman to stop drinking or to drink less (Table 7). Only $7.4 \%$ of the students would do nothing and $3.6 \%$ said they would encourage the woman to drink more. $(\chi 2(2, \mathrm{~N}=725)=17.972, p<$ .0001).

Table 7. Personal Reaction to Woman's Flushing

\begin{tabular}{lrrrrrr}
\hline What would you do if a & \multicolumn{2}{c}{ Male } & \multicolumn{2}{c}{ Female } & \multicolumn{2}{c}{ Total } \\
woman flushed? & $\mathrm{N}$ & $\%$ & $\mathrm{~N}$ & $\%$ & $\mathrm{~N}$ & $\%$ \\
\cline { 2 - 6 } Encourage her to drink more & 22 & 6.5 & 4 & 1.0 & 26 & 3.6 \\
Encourage her to drink less or & 287 & 84.7 & 358 & 92.7 & 645 & 89.0 \\
stop & & & & & & \\
Do nothing & 30 & 8.8 & 24 & 6.2 & 54 & 7.4 \\
Total & 339 & 100.0 & 386 & 100.0 & 725 & 100.0 \\
\hline$\chi 2=17.972, p<.0001$ & & & & & &
\end{tabular}

Students' Beliefs About Other Peoples' Reactions to a Person Who Flushes While Drinking

The survey questionnaire asked students what they believed other people in their group would do when they observed someone in their group flushing while drinking.

\section{Beliefs about men's reactions to a man flushing}

Student's beliefs about other men's reactions to a man flushing did not differ by gender. Approximately half the students, males (49.9\%) and females (56.0\%), believed men would ignore another man's flushing; and $18.9 \%$ of males and $19.4 \%$ of females believed men would encourage the man to drink more. A third of the males (31.9\%) and $24.6 \%$ of the females believed men would encourage the man to drink less $(\chi 2=4.777, p=.092, n=727)$. 
Beliefs about women's reactions to a man flushing

The beliefs were quite different when students were asked about how other women would react if a man was flushing. The majority of males (81.7\%) and females (88.6\%) thought women in the group would encourage the flushing man to drink less. Only $13.9 \%$ of the males and $10.1 \%$ of the females thought the women would ignore the man's flushing $(\chi 2=9.563, \mathrm{p}=.008)$.

\section{Beliefs about men's reactions to a woman flushing}

A high percentage of both females $(90.9 \%)$ and males $(80.8 \%)$ believed that men would encourage the flushing woman to stop drinking or drink less. More males (13.3\%) than females $(7.5 \%)$ believed that men would ignore the woman's flushing. The small cell sizes make this Chi-square unreliable

Beliefs about women's reactions to a woman flushing.

Both males (76.7\%) and females (72.5\%) thought women would encourage the flushing woman to drink less or stop drinking. Similar proportions of males (10.9\%) and females (12.4\%) thought women would encourage a woman who flushed to drink more. Very few males (5.9\%) and females $(1.6 \%)$ thought women would ignore the woman's flushing $\left(\chi^{2}=1.684, p=.431\right)$.

\section{DISCUSSION}

In this study we explored the social meaning of and social reactions to the physiological consequences of drinking, exhibited as flushing, in Chinese university students. 
The data collected for this study showed that more than half the students interpreted flushing as having no special meaning. It is clear from Chinese history that flushing has been recognized for a long time. However, the physiological significance of flushing as an indicator of the body's inability to metabolize alcohol is only recent knowledge. The concept that a flushing person should reduce or stop their consumption of alcohol to prevent the further accumulation of acetaldehyde in their body is clearly not recognized by this sample of university students.

Among those who suggested a special meaning there were significant gender differences. Males were more likely to suggest flushing had either no meaning or that it was a sign that the person could drink more. Females were more likely to say flushing meant the flusher should stop drinking. The gender differences suggest social values related to drinking and gender. Social values are learned. Beliefs did not differ by year in school, suggesting these values were learned early and independently of formal education.

Flushers and nonflushers did not differ significantly in their interpretation of the meaning of flushing, suggesting the interpretation of flushing was not related to flushing experience. However, drinkers and nondrinkers did differ in their interpretation of flushing. Nondrinkers were more likely than drinkers to say flushing meant stop drinking, suggesting that drinking experience, with or without adverse reactions, lessened the perception of flushing as a sign to slow down or stop. The reason attitudes differ by drinking type but not by flushing type is not clear.

How do students who flush when they drink alcohol feel about their own flushing?

Flushers' beliefs about the meaning of their own flushing did not differ markedly from the beliefs about flushing in the total sample. More female flushers than male flushers said 
flushing meant stop drinking. Male flushers were only slightly more likely than female flushers to say a flusher could keep drinking but drink less or keep drinking the same amount, suggesting only small gender-specific beliefs about alcohol use among the flushers.

\section{How do students respond to other students who flush when they drink alcohol?}

Responses to general questions about the meaning of flushing identified a relatively low proportion of students who said that a flushing person should stop drinking. However, the responses were quite different to questions that identified the gender of the flusher. If a woman flushed while drinking almost all students (male and female) said they would encourage her to stop drinking or drink less. Students responded differently when asked what they would do if a man flushed: overall fewer students would encourage the flushing man to stop or drink less, with females being likelier to do this than males

What do students believe will be the reaction of other students to someone who is flushing?

The gender differences in the perceived meaning of flushing were seen again in students' responses to a question about what they believed would be the reaction of other students to a flushing student. About half of males and females indicated that men would ignore flushing if a man was flushing; however, few males or females believed that men would ignore flushing if a woman was flushing. We also found that around $20 \%$ of both males and females expected other men would encourage the flushing man to drink more.

\section{STUDY LIMITATIONS}

This is one of the first studies of how Chinese university students understand of the meaning of alcohol-related flushing and their social responses to flushing. The sample was not random and 
was limited to four cities in northeastern and central China. About one third (32.9\%) of all questionnaires were eliminated from analysis because of inconsistent or uncompleted answers; however, students not included in the analysis did not appear significantly different from students who were included. We used a classification of alcohol use (nondrinkers, occasional drinkers, current drinkers) that was limited in its discrimination of drinking patterns and could have misclassified some individuals. Surveys on alcohol use and flushing are novel for students in China, which could affect the fidelity of the self-reported responses. Both alcohol use and flushing are viewed as unremarkable behaviors, so self-reported recall of these events on a survey may not be totally accurate. This study on attitudes toward flushing and alcohol use cannot be used to infer an effect of flushing on actual alcohol use.

\section{CONCLUSION}

Most of the university students in this sample did not see flushing as an indicator to stop or slow down drinking. Gender differences in the social reaction to alcohol-related flushing raise interesting questions as to how flushing acts as a potential protective factor against alcohol misuse. The effects of gender on responses to questions about facial flushing seem to reflect the cultural belief that drinking has traditionally not been an acceptable behavior for females while it has been an acceptable behavior for men, a pattern also observed by Hao et al. ${ }^{25,26}$ Likewise, among men, the ability to drink significant amounts of alcohol without showing its effect may be greatly admired, which is perhaps why almost $20 \%$ of the men in our study say they would encourage a flushing man to drink more. 


\section{References}

1. Lam TL, Chim D. Controlling alcohol-related global health problems. Asia Pac J Public Health 2010;22(3suppl):203S-208S.

2. Heath DB. Drinking Occasions: Comparative Perspectives on Alcohol and Culture. Philadelphia, PA: Taylor and Francis; 2000.

3. Fromme K, deWit H, Hutchison KE, Ray L, Corbin WR, Cook, TAR, Wall TL, Goldman D. Biological and behavioral markers of alcohol sensitivity. Alcohol Clin Exp Res. $2004 ; 28(2): 247-256$.

4. Slutske WS, Heath AC, Madden PA, Bucholz KK, Dinwiddie SH, Dunne MP, Statham DS, Whitfield JB, Martin NG. Is alcohol-related flushing a protective factor for alcoholism in caucasians? Alcohol Clin Exp Res. 1995;19(3):582-592.

5. Johnson RC, Nagoshi CT. (1990). Asians, Asian-Americans and alcohol. J Psychoactive Drugs. 1990;22(1):45-52.

6. Wall TL, Ehlers CL. Acute effects of alcohol on P300 in Asians with different ALDH2 genotypes. Alcohol Clin Exp Res. 1995;19(3):617-622.

7. Luo HR, Wu GS, Pakstis AJ, Tong L, Oota H, Kidd KK, Zhang YP. Origin and dispersal of atypical aldehyde dehydrogenase ALDH2487Lys. Gene. 2009;435(1-2):96-103.

8. Cook TA, Luczak SE, Shea SH, Ehlers CL, Carr LG, Wall TL. Associations of ALDH2 and ADH1B genotypes with response to alcohol in Asian Americans. J Stud Alcohol. 2005;66:196-204.

9. Luczak SE, Elvine-Kreis B, Shea SH, Carr LG, Wall TL. (2002). Genetic risk for alcoholism relates to level of response to alcohol in Asian-American men and women. J Stud Alcohol. 2002;63:74-82. 
10. Wall TL, Horn SM, Johnson ML, Smith TL, Carr LG. Hangover symptoms in Asian Americans with variations in the aldehyde dehydrogenase (ALDH2) gene. J Stud Alcohol. 2000;61(1):13-17.

11. Luczak SE, Shea SH, Hsueh AC, Chang J, Carr LG, Wall TL. ALDH2 is associated with a decreased likelihood of alcohol-induced blackouts in Asian American college students. $J$ Stud Alcohol. 2006;67:349-353.

12. Wall TL, Thomasson HR, Schuckit MA, Elhlers CL. Subjective feelings of alcohol intoxication in Asians with genetic variations of ALDH2 alleles. Alcohol Clin Exp Res, 1992;16(5):991-995.

13. Unger JB. Genetic and environmental influences on smoking, alcohol use, and psychological characteristics among adolescent twins in Qingdao, China. Asia Pac J Public Health May 19,2010 http://aph.sagepub.com/content/early/2010/05/18/1010539509351052.abstract?rss=1 Accessed May 20, 2010.

14. Ewing JA, Rouse BA, Pellizzari ED. Alcohol sensitivity and ethnic background. Am J Psychiat. 1974;131(2):206-210.

15. Zeiner AR, Paredes A,Christensen HD. The role of acetaldehyde in mediating reactivity to an acute dose if ethanol among different racial groups. Alcohol Clin Exp Res, $1979 ; 3(1): 11-18$.

16. Schwitters SY, Johnson RC, McClearn GE, Wilson JR. Alcohol use and the flushing response in different racial- ethnic groups. J Stud Alcohol. 1982;42(11):1259-1262.

17. Johnson RC. (1989). Flushing reaction and alcohol use. In: Spiegler D, Tate D, Aitken S, Christian C, eds. Alcohol Use Among U.S. Ethnic Minorities: Proceedings of a 
Conference on the Epidemiology of Alcohol Use and Abuse Among Ethnic Minority

Groups, September 1985. National Institute on Alcohol Abuse and Alcoholism Research Monograph No.18. DHHS Pub. No (ADM) 89-1435. Bethesda, MD: NIAAA, 1989:383396.

18. Nakawatase TV, Yamamoto J, Sasao T. The association between fast-flushing response and alcohol use among Japanese Americans. J Stud Alcohol. 1993;54:48-53.

19. Hendershot CS, MacPherson L, Myers MG, Carr LG, Wall TL. Psychosocial, cultural and genetic influences on alcohol use in Asian American youth. J Stud Alcohol, 2005;66:185195.

20. Suzuki K, Matsushita S, Ishii T. Relationship between the flushing response and drinking behavior among Japanese high school students. Alcohol Clin Exp Res. 1997;21(9):17261729.21. Stacy AW, Zogg JB, Unger JB, Dent CW. Exposure to televised alcohol ads and subsequent adolescent alcohol use. Am J Health Behav, 2004;28(6):498-509.

22. Parrish KM, Higuchi S, Stinson FS, Dufour MC, Towle LH, Harford TC. Genetic or cultural determinants of drinking: a study of embarrassment at facial flushing among Japanese and Japanese-Americans. J Subst Abuse. 1990;2:439-447.

23. Newlin DB. The skin-flushing response: autonomic, self-report, and conditioned responses to repeated administrations of alcohol in Asian men. J Abnorm Psychol. 1989;98(4):421425 .

24. Zhang JG, Merrick TM, Newman IM, Qian L. Jiu hou lian hong de she hui han yi [The social meaning of alcohol-related flushing.] Zhongguo Jiankang Jiaoyu [Chinese Journal of Health Education], 2007;23(4):271-274. 
25. Hao W, Su ZH, Liu BL, Zhang K, Yang HQ, Chen SA, Biao MZ, Cui C. Drinking and drinking patterns and health status in the general population of five areas of China. Alcohol Alcoholism. 2004;39(1):43-52.

26. Hao, W., \& Young, D. (2000). Drinking patterns and problems in China. Journal of Substance Use. 5, 71-78. 